\title{
The flower-visiting social wasps (Hymenoptera, Vespidae, Polistinae) in two areas of Rio Grande do Sul State, southern Brazil
}

\author{
Marcel G. Hermes ${ }^{1,2}$ \& Andreas Köhler ${ }^{1}$
}

${ }^{1}$ Laboratório de Entomologia, Departamento de Biologia e Farmácia, Universidade de Santa Cruz do Sul, Av. Independência, No 2293 , Bairro
Universitário, 96815-900, Santa Cruz do Sul-RS, Brasil. andreas@unisc.br
${ }^{2}$ Current address: Departamento de Zoologia, Universidade Federal do Paraná, Cx. Postal 19020, 81531-980, Curitiba-PR, Brasil.
mghermes@gmail.com

\begin{abstract}
The flower-visiting social wasps (Hymenoptera, Vespidae, Polistinae) in two areas of Rio Grande do Sul State, southern Brazil. The structure of flower-visiting social wasps' assemblages in the CPCN Pró-Mata of São Francisco de Paula and in the Green Belt of Santa Cruz do Sul, Rio Grande do Sul, are characterized. A total of 879 polistine wasps were collected, of which 475 (11 spp.) in the CPCN and 404 (21 spp.) in the Green Belt, from September 1997 to April 2001 and from September 2001 to April 2004, respectively. Foraging social wasps were observed on flowers of 36 species of angiosperms (20 families) in the Green Belt, and on flowers of 54 species of angiosperms (21 families) in the CPCN. Asteraceae was the most visited plant family on both studied localities. A list of pant species visited by the polistines is provided.
\end{abstract}

KEYWORDS. Araucaria Forest; Asteraceae; Atlantic Forest; floral preferences; Vespidae.

RESUMO. Vespas sociais (Hymenoptera, Vespidae, Polistinae) visitantes de flores em duas áreas no Rio Grande do Sul, Brasil. A estrutura da assembléia de vespas sociais que visitam flores no CPCN Pró-Mata de São Francisco de Paula e no Cinturão Verde de Santa Cruz do Sul, Rio Grande do Sul, são caracterizadas. Do total de 879 polistíneos, 475 (11 spp.) foram coletados no CPCN, e 404 (21 spp.) no Cinturão Verde entre Setembro de 1997 a Abril de 2000 e Setembro de 2001 a Abril de 2004, respectivamente. Vespas sociais foram observadas em flores de 36 espécies de angiospermas (20 famílias) no Cinturão Verde, e em flores de 54 espécies de angiospermas (21 famílias) no CPCN. Asteraceae foi a família de planta que mais recebeu visitas por parte das vespas nas duas localidades estudadas. Uma lista com as espécies de plantas visitadas pelos polistíneos é apresentada.

PALAVRAS-CHAVE. Asteraceae; Mata Atlântica; Mata com Araucária; preferências florais; Vespidae.

Social wasps (Vespidae, Polistinae) comprise 26 genera and about 950 species with cosmopolitan distribution (Carpenter $\&$ Marques 2001). For Rio Grande do Sul State, 8 genera and 43 species have been recorded (Richards 1978). Nevertheless, studies of fauna-flora interactions are restricted to the flowervisiting bee communities of Serra do Sudeste (Schlindwein \& Wittman 1995) and Serra Geral (Wilms et al. 1997; HarterMarques \& Engels 2003).

The aim of this study was the characterization of the structure of flower-visiting social wasps' assemblages in two areas of Rio Grande do Sul State, southern Brazil. A discussion concerning the floral spectrum visited by the polistines is presented.

\section{MATERIALAND METHODS}

Study Sites. Green Belt of Santa Cruz do Sul, Rio Pardo Valley, Central Rio Grande do Sul - The Green Belt of Santa Cruz do Sul is located inside the urban area of the Santa Cruz do Sul City, at $29^{\circ} 43^{\prime} \mathrm{S}-52^{\circ} 25^{\prime} \mathrm{W}$, between the limits of the Serra Geral and Depressão Central. The altitude varies between 50 to $150 \mathrm{~m}$ asl, and the climate is characterized as humid, with mean temperatures under $15^{\circ} \mathrm{C}$ in winter months and above $20^{\circ} \mathrm{C}$ in summer months. The area comprises 465 ha with secondary forest vegetation, mainly composed of Atlantic Rainforest species such as Euterpe edulis and Schinus terebenthifolius (Alves \& Collischonn, 2001). This study was conducted from September 2001 to April 2004.

CPCN Pró-Mata, São Francisco de Paula, Northeast Rio Grande do Sul - The CPCN Pró-Mata is located in the Serra Geral at $29^{\circ} 30^{\prime} \mathrm{S}-50^{\circ} 10^{\prime} \mathrm{W}$. The altitude lies between 600 and $1.000 \mathrm{~m}$ asl. The climate is characterized as temperate-humid with mean temperatures of $22^{\circ} \mathrm{C}$ in summer months reaching negative $5^{\circ} \mathrm{C}$ in winter months. The area comprises about 5.000 ha with primary and secondary vegetation and grasslands mostly on cleared former Araucaria forest areas (Wilms et al. 1997). This study was conducted from September 1997 to April 2000.

Sampling. Flower-visiting social wasps were collected on blooming trees, shrubs and herbs, following Sakagami et al. (1967). The wasps were collected with entomological nets attached to long articulated fishing rods in order to reach the upper canopy (Carvalho et al. 1995). Samples of the visited plants were also collected for identification. Social wasps were identified to species level. The material collected at CPCN PróMata is deposited at Museu de Ciências e Tecnologia of Pontificia Universidade Católica do Rio Grande do Sul. The 
material collected at the Green Belt of Santa Cruz do Sul is deposited at Coleção Entomológica of the Universidade de Santa Cruz do Sul and in the herbarium of the same institution.

Data Analysis. For the comparison between the structure of the two flower-visiting social wasp assemblages, the following ecological indexes were adopted: the criteria proposed by Lobo \& Leighton (1986) for species abundance and dominance, where the total number of individuals is divided by the total number of species in the site (those species whose number of individuals is higher than the mean number of individuals per species are considered abundant); the NB index proposed by Shannon for species trophic niche breadth (Pielou 1972); and the Colwell \& Futuyama (1971) NO index for species niche breadth overlap. The Detrended Correspondence Analysis (DCA) (Hill \& Gauch 1980) and the Indicator Species Analysis (IndVal) (Dufrene \& Legendre 1997) were performed to verify the social wasp assemblages' floral preferences and the faithfulness of occurrence of a species in a particular site, respectively, using the software Pc-Ord 4.10 for Windows (McCune \& Mefford 1999). The Detrended Correspondence Analysis is an eigenanalysis ordination technique based on reciprocal averaging (Hill 1973). DCA is geared to ecological data sets and the terminology is based on samples (in the present study, the most visited plant families) and species (only abundant social wasps were considered).

\section{RESULTS}

A total of 879 polistine wasps were collected during this study, 404 (21 spp.) in the Green Belt of Santa Cruz do Sul, and 475 (11 spp.) in the CPCN Pró-Mata of São Francisco de Paula (Table I). Seven species were abundant in the Green Belt, and 4 species were abundant in the CPCN Pró-Mata (Figs. 1 and 2). It should be of special interest that only one individual of the tribe Polistini was collected in the CPCN area, while it represented $50 \%$ of the collected flower-visiting social wasps in the Green Belt area.

Foraging social wasps were observed on flowers of 36 species of angiosperms (20 families) in the Green Belt, and on flowers of 54 species of angiosperms (21 families) in the CPCN Pró-Mata (Table II). Asteraceae was more visited in both localities (Figs. 3 and 4). However, in the Green Belt the family Apiaceae was also commonly visited by the polistines, while in the CPCN Pró-Mata, Cunoniaceae and Theaceae were also important food suppliers to the visiting social wasps.

It is also notable in the figures 3 and 4 that the visitation to Asteraceae and Apiaceae in the Green Belt was much higher than the most important visited plants in the CPCN Pró-Mata.

The workers of Polistes actaeon visited flowers of 18 plant species in the Green Belt of Santa Cruz do Sul. The trophic niche breadth for this species was the highest among the species found in the Green Belt, as well as its mean number of individuals collected per plant species (Fig. 5). Polistes cinerascens also presented a high value for the trophic niche breadth, but it resulted from the generalist behavior of this
Table I. Species of Polistinae collected in the two study sites and respective number of individuals. GB = Green Belt of Santa Cruz do Sul; CPCN = Centro de Pesquisa e Conservação da Natureza Pró-Mata of São Francisco de Paula.

\begin{tabular}{lccr}
\hline \multirow{2}{*}{ Polistinae Species } & & \multicolumn{2}{c}{$\begin{array}{c}\mathrm{N}^{\circ} \text { of } \\
\text { Individuals }\end{array}$} \\
\cline { 3 - 5 } & Acronyms & GB & CPCN \\
\hline Tribe Epiponini & & & \\
Agelaia multipicta (Haliday, 1836) & AGMP & 11 & 28 \\
Agelaia vicina (Saussure, 1854) & AGVI & 4 & 31 \\
Brachygastra lecheguana (Latreille, 1824) & BRLE & 33 & 113 \\
Polybia fastidiosuscula Saussure, 1854 & POFT & 4 & \\
Polybia ignobilis (Haliday, 1836) & POIG & 54 & 1 \\
Polybia minarum Ducke, 1906 & POMN & & 62 \\
Polybia platycephala Richards, 1951 & POPT & & 119 \\
Polybia scutellaris (White, 1841) & POSC & 12 & 1 \\
Polybia sericea (Olivier, 1792) & POSE & 31 & \\
Polybia sp. & POSP & & 3 \\
$\begin{array}{l}\text { Protonectarina sylveirae (Saussure, 1854) } \\
\text { Synoeca cyanea (Fabricius, 1775) }\end{array}$ & PRSY & 8 & 79 \\
& SYCY & 20 &
\end{tabular}

Tribe Mischocyttarini

Mischocyttarus drewseni Saussure, 1857 MIDW $\quad 15$

Mischocyttarus riograndensis

Richards, 1978

Mischocyttarus rotundicollis

(Cameron, 1912)

\begin{tabular}{lcr} 
MIRG & 4 & \\
MIRT & 6 & \\
& & \\
& & \\
PTAC & 92 & \\
PTBG & 7 & \\
PTBL & 2 & \\
PTCV & 6 & \\
PTCF & 4 & \\
PTCN & 13 & \\
PTCO & 7 & \\
PTPF & & 1 \\
PTVR & 49 & \\
PTSP & 22 & \\
& 404 & 475 \\
\hline
\end{tabular}

Tribe Polistini

Polistes actaeon Haliday, 1836

Polistes biguttatus Haliday, 1836

Polistes billardieri Fabricius, 1804

Polistes cavapyta Saussure, 1853

Polistes cavapytiformis Richards, 1978

Polistes cinerascens Saussure, 1854

Polistes consobrinus Saussure, 1858

Polistes pacificus Fabricius, 1804

Polistes versicolor (Olivier, 1792)

Polistes sp.

404

475

species, since its mean number of individuals collected per plant species was very low. On the other hand, the high number of workers of Polybia ignobilis that visited Eryngium horridum (Apiaceae) reflected an intermediate position of its trophic niche breadth, despite its mean number of individuals collected per plant species being remarkably high. Finally, Polybia fastidiosuscula has a restricted trophic niche breadth, as well as Agelaia vicina, Mischocyttarus riograndensis, Polistes billardieri and Polistes consobrinus.

In the CPCN Pró-Mata, the epiponine Brachygastra lecheguana visited flowers of 26 plant species. Consequently, its trophic niche breadth was the highest among the flowervisiting social wasps of this area (Fig. 6). Other species showing a wide trophic niche breadth were Protonectarina sylveirae, Polybia platycephala and Polybia minarum. Females of Mischocyttarus drewseni were captured mostly on Baccharis 


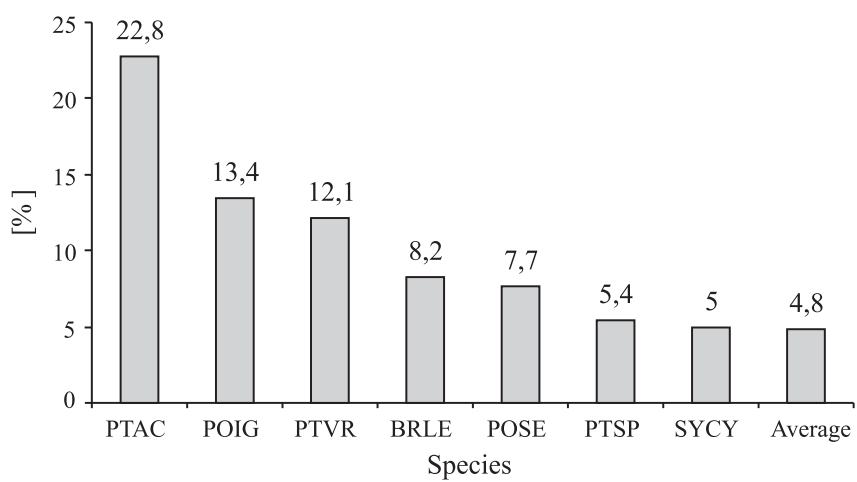

Fig. 1. Abundant species of flower-visiting social wasps collected in the Green Belt of Santa Cruz do Sul (Lobo \& Leighton 1986). Acronyms as in Table I. Average $=$ mean number of individuals per wasp species found in the study area.

tridentata and Baccharis myriocephala (Asteraceae), which resulted in its elevated mean number of individuals captured per plant species and its relatively low value of trophic niche breadth, since a very low number of individuals was collected from flowers of four other plant species. Polistes pacificus, Polybia ignobilis, Polybia scutellaris and Polybia sp. were very rare in the CPCN Pró-Mata.

For the flower-visiting social wasps collected in the Green Belt of Santa Cruz do Sul, $72,4 \%$ of the calculated trophic niche overlap values range from 0,0 to 0,3 (Table III). $10 \%$ of the calculated values were considered intermediate $(0,4)$, and only $17,4 \%$ of the cases showed a high congruence in the floral resource utilization, ranging from 0,5 to 0,8 . A remarkable case of low congruence regarding the use of floral resources is that of Polistes actaeon, which visited the widest floral spectrum in the Green Belt.

In the CPCN Pró-Mata of São Francisco de Paula, 87,3\% of the calculated trophic niche overlap values range from 0,0 to 0,3 (Table IV). Only 3,6\% of the values were considered intermediate $(0,4)$ and $9,1 \%$ were considered values of high congruence $(0,5$ to 0,7$)$. The highest congruence values regarding the use of food resources were between Polybia

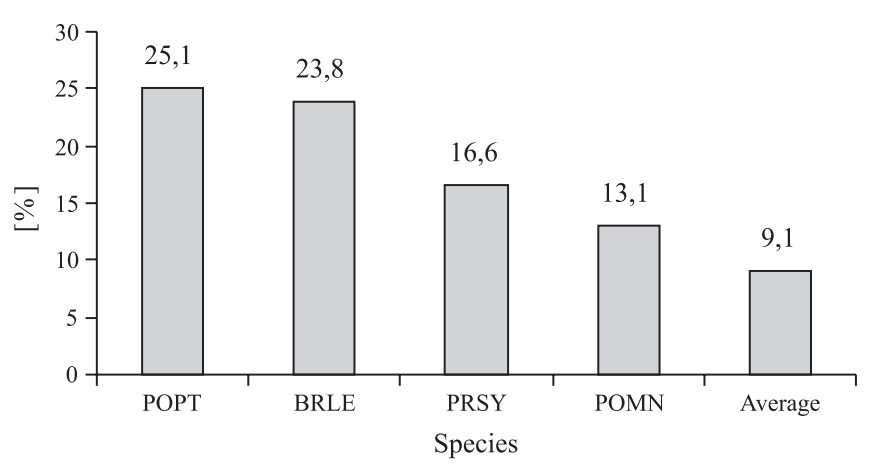

Fig. 2. Abundant species of flower-visiting social wasps collected in the CPCN Pró-Mata of São Francisco de Paula (Lobo \& Leighton 1986). Acronyms as in Table I. Average $=$ mean number of individuals per wasp species found in the study area.

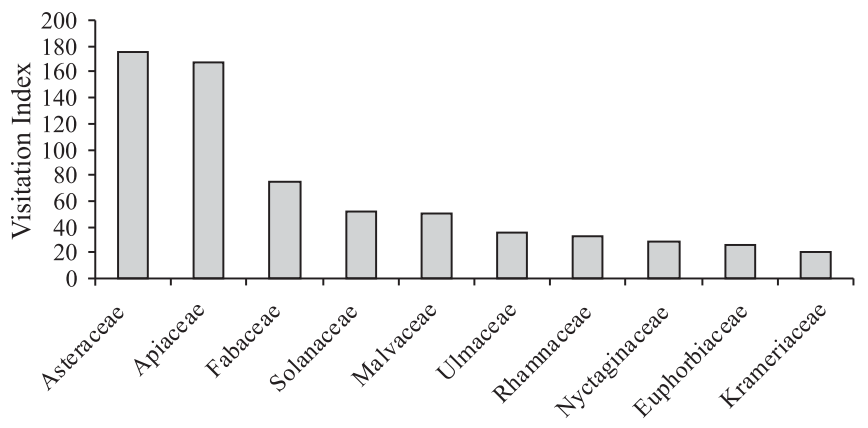

Fig. 3. Ranking of the most important plant families as food resource for polistine wasps in the Green Belt. The ten most visited plant families per wasp species were ranked, 10 being the most visited one, 9 the second most visited, and so on. Addition of rank points gives the visitation index (Wilms et al. 1996).

minarum and Polybia platycephala, and between Polybia platycephala and Protonectarina sylveirae. These species were abundant visitors of a wide spectrum of floral resources.

Social wasp distribution in relation to the visited floral spectrum is visualized through the multivariate exploratory Detrended Correspondence Analysis (DCA) (Fig. 7). It is visible that the two study sites grouped separately from each other. In the left side of the Axis 2 is plotted the Green Belt of Santa Cruz do Sul, with Asteraceae and Apiaceae placed near the middle of all polistine species, showing their importance to social wasp nutritional demand. Despite Synoeca cyanea was a frequent visitor of Asteraceae and Apiaceae species, its resource spectrum also included species of the families Rhamnaceae, Ulmaceae, Krameriaceae and Fabaceae, which occasioned its plotting in the upper portion of the left side of the graphic. On the other hand, Polistes versicolor was also a frequent visitor of Asteraceae and Apiaceae species, but also visited plants of the families Mimosaceae and Nyctaginaceae in avoidance of species of Rhamnaceae, Ulmaceae, Krameriaceae and Fabaceae, occasioning its plotting on the lower portion of the left side of the graphic. Finally, Polistes actaeon is placed near Axis 1, but on the extreme left side. As

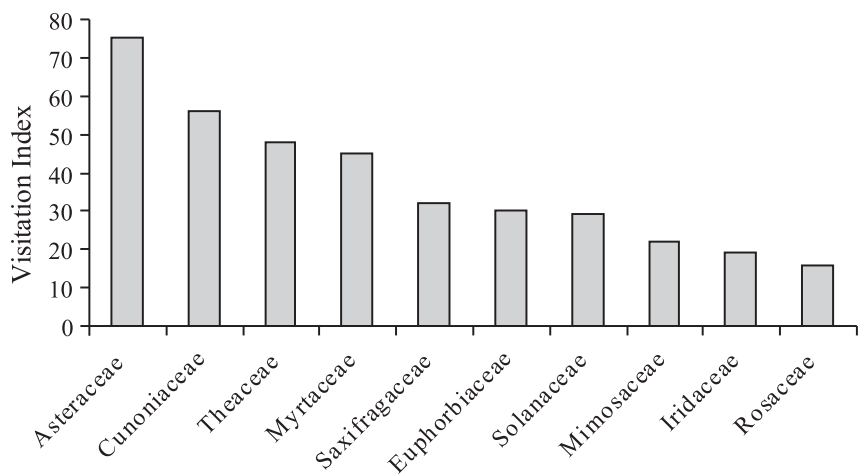

Fig. 4. Ranking of the most important plant families as food resource for polistine wasps in the CPCN Pró-Mata. The ten most visited plant families per wasp species were ranked, 10 being the most visited one, 9 the second most visited, and so on. Addition of rank points gives the visitation index (Wilms et al. 1996). 
Table II. Plant families/species visited by the social wasps in the two study sites. $\mathrm{GB}=$ Green Belt of Santa Cruz do Sul; $\mathrm{CPCN}=$ Centro de Pesquisa e Conservação da Natureza Pró-Mata of São Francisco de Paula.

\begin{tabular}{|c|c|c|}
\hline Plant Family/Species & Area & $\begin{array}{c}\text { Number } \begin{array}{c}\text { Number } \\
\text { of visiting } \\
\text { of visitors polistine } \\
\text { species }\end{array}\end{array}$ \\
\hline
\end{tabular}

Amaranthaceae (AMA)

Celosia argentea

Anacardiaceae (ANA)

Astronium balansae

Apiaceae (API)

Eryngium horridum

Eryngium megapotamicum

Aquifoliaceae (AQU)

Ilex microdonta

Asclepiadaceae (ASC)

Asclepia campestris

Oxypetalum sp.

Asteraceae (AST)

Baccharidastrum triplinervum

Baccharis anomala

Baccharis camporum

Baccharis crispa

Baccharis megapotamica

Baccharis myriocephala

Baccharis phyteumoides

Baccharis pseudovillosa

Baccharis semiserrata

Baccharis sp. 1

Baccharis sp. 2

Baccharis tridentata

Baccharis trimera

Baccharis uncinella

Cosmos bipinnatus

Elephantopus mollis

Eupatorium betonicaeforme

Eupatorium bupleurifolium

Eupatorium gaudichanianum

Eupatorium laevigatum

Eupatorium serratum

Hypochoeris radicata

Mikania burchellii

Mikania paranensis

Senecio brasiliensis

Senecio desiderabilis

Solidago chilensis

Vernonia discolor

Vernonia florida

Vernonia oxyodonta

Vernonia polyanthes

Vernonia puberula

Begoniaceae (BEG)

Begonia fruticosa

Caesalpiniaceae (CAE)

Cassia eptafila

Cunoniaceae (CUN)

Lamanonia speciosa

Euphorbiaceae (EUP)

Actinostemon concolor

Croton erythroxyloides

Sapium glandulatum

Fabaceae (FAB)

Bauhinia candicans

Desmodium affine

Desmodium sp.

$\begin{array}{ccc}\text { GB } & 1 & 1 \\ \text { GB } & 2 & 2 \\ \text { GB } & 92 & 17 \\ \text { GB } & 12 & 8\end{array}$

$\begin{array}{lll}\mathrm{CPCN} & 3\end{array}$

$\begin{array}{cl}\text { GB } & 3 \\ \text { CPCN } & 1\end{array}$

$\mathrm{CPCN}$
$\mathrm{CPCN}$

$\mathrm{CPCN}$
$\mathrm{CPCN}$

CPCN

CPCN

CPCN

GB

CPCN

CPCN

CPCN

GB

CPCN

GB

CPCN

GB

$\mathrm{GB}$
$\mathrm{CPCN}$

CPCN

CPCN

GB

CPCN

CPCN

CPCN

CPCN

CPCN

GB

CPCN

GB

CPCN

GB

GB

GB

GB

CPCN

3

1

2
1

1

3

2

12

2

2

4

2

3

4

9

2
2

3

11

1

2
7
3

3
1

1

1

1

1

7

6

7

4

$\begin{array}{lll} & 1 & 1\end{array}$

GB

$\begin{array}{lll}\text { CPCN } & 68 & 7\end{array}$

GB

CPCN

CPCN

4
4
6

GB

GB

GB
Table II. Cont.

Plant Family/Species

Area

Number Number

visiting

of visitors polistine

species

Indigofera suffruticosa

Iridaceae (IRI)

Calydorea crocoides

Cypella herbertii

Sisyrinchium avenaceum

Krameriaceae (KRA)

Krameria sp.

Lamiaceae (LAM)

Ocimum selloi

Lythraceae (LYT)

Heimia sp.

Malvaceae (MAL)

Sida potentilloides

Sida rhombifolia

Melastomataceae (MET)

Miconia cinerascens

Meliaceae (MEL)

Trichilia claussenii

Mimosaceae (MIM)

Inga lentiscifolia

Mimosa bimucromata

Mimosa scabrella

Myrtaceae (MYR)

Acca sellowiana

Hexachlamys italiensis

Myrceugenia euosma

Myrceugenia myrcioides

Myrceugenia ovata

Myrceugenia oxysepala

Myrcia obtecta

Nyctaginaceae (NYC)

Bougainvillaea glabra

Oleaceae (OLE)

Ligustrum japonicum

Onagraceae (ONA)

Fuchsia regia

Oxalidaceae (OXA)

Oxalis perdicaria

Rhamnaceae (RHA)

Hovenia dulcis

Rosaceae (ROS)

Prunus sellowii

Sapindaceae (SAP)

Allophylus edulis

Saxifragaceae (SAX)

Escallonia bifida

Solanaceae (SOL)

Solanum acerosum

Solanum sp.

Solanum variabile

Vassobia breviflora

Theaceae (THE)

Gordonia fruticosa

Thymelaeaceae (THY)

Daphnopsis fasciculata

Ulmaceae (ULM)

Trema micrantha

Verbenaceae (VER)

Verbena alata

Verbena bonariensis

Verbena hirta

$\begin{array}{ccc}\text { GB } & 9 & 6 \\ \text { CPCN } & 1 & 1 \\ \text { CPCN } & 1 & 1 \\ \text { CPCN } & 1 & 1 \\ \text { GB } & 4 & 3 \\ \text { CPCN } & 1 & 1 \\ \text { GB } & 1 & 1 \\ & & \\ \text { CPCN } & 4 & 2 \\ \text { GB } & 36 & 6 \\ \text { CPCN } & 2 & 2\end{array}$

GB 1

$\begin{array}{lll}\mathrm{CPCN} & 18 & 3\end{array}$

$\begin{array}{ccc}\mathrm{GB} & 5 & 2 \\ \mathrm{CPCN} & 11 & 3\end{array}$

$\begin{array}{lll}\mathrm{CPCN} & 9 & 3\end{array}$

$\begin{array}{lll}\mathrm{CPCN} & 1 & 1\end{array}$

$\begin{array}{lll}\mathrm{CPCN} & 3 & 1\end{array}$

CPCN $11 \quad 2$

$\begin{array}{lll}\mathrm{CPCN} & 1 & 1 \\ \mathrm{CPCN} & 1 & 1\end{array}$

$\begin{array}{lll}\mathrm{CPCN} & 1 & 1\end{array}$

$\begin{array}{lll}\text { GB } & 6 & 4\end{array}$

GB 2

$\begin{array}{lll}\mathrm{CPCN} & 5 & 2\end{array}$

$\begin{array}{lll}\mathrm{CPCN} & 2 & 1\end{array}$

$\begin{array}{lll}\text { GB } & 8 & 4\end{array}$

CPCN 2

GB 1

$\begin{array}{lll}\text { CPCN } & 11\end{array}$

$\begin{array}{lll}\text { GB } & 6 & 5\end{array}$

$\begin{array}{ccc}\text { GB } & 3 & 3 \\ \mathrm{CPCN} & 5 & 3\end{array}$

$\begin{array}{lcl}\mathrm{CPCN} & 10 & 3\end{array}$

$\begin{array}{lll}\mathrm{CPCN} & 50\end{array}$

$\begin{array}{lll}\mathrm{CPCN} & 1 & 1\end{array}$

GB 6

$\begin{array}{lll}\mathrm{CPCN} & 2 & 2\end{array}$

$\begin{array}{ccc}\mathrm{GB} & 6 & 3 \\ \mathrm{CPCN} & 1 & 1\end{array}$


Table III. Trophic niche overlap of polistine wasps in the Green Belt of Santa Cruz do Sul. Acronyms as in Table I.

\begin{tabular}{|c|c|c|c|c|c|c|c|c|c|c|c|c|c|c|c|c|c|c|c|c|}
\hline \multirow{2}{*}{$\overline{\mathrm{AGMP}}$} & \multicolumn{2}{|c|}{ AGMP AGVI } & BRLE & POFT & \multicolumn{2}{|c|}{ POIG P } & \multicolumn{2}{|c|}{ POSE PRSY } & SYCY & \multicolumn{2}{|c|}{ MIRG MIDW } & \multicolumn{3}{|c|}{ MIRT PTSP PTAC } & \multicolumn{2}{|c|}{ PTBG PTBL } & \multicolumn{4}{|c|}{ PTCV PTCF PTCN PTCO } \\
\hline & & & & & & & & & & & & & & & & & & & & \\
\hline AGVI & 0,0 & & & & & & & & & & & & & & & & & & & \\
\hline BRLE & 0,1 & 0,3 & & & & & & & & & & & & & & & & & & \\
\hline POFT & 0,1 & 0,0 & 0,1 & & & & & & & & & & & & & & & & & \\
\hline POIG & 0,1 & 0,3 & 0,5 & 0,0 & & & & & & & & & & & & & & & & \\
\hline POSC & 0,3 & 0,3 & 0,5 & 0,1 & 0,6 & & & & & & & & & & & & & & & \\
\hline POSE & 0,2 & 0,3 & 0,5 & 0,0 & 0,5 & 0,4 & & & & & & & & & & & & & & \\
\hline PRSY & 0,0 & 0,3 & 0,3 & 0,0 & 0,5 & 0,3 & 0,4 & & & & & & & & & & & & & \\
\hline SYCY & 0,2 & 0,2 & 0,2 & 0,1 & 0,3 & 0,1 & 0,3 & 0,4 & & & & & & & & & & & & \\
\hline MIRG & 0,0 & 0,3 & 0,3 & 0,0 & 0,3 & 0,3 & 0,2 & 0,3 & 0,1 & & & & & & & & & & & \\
\hline MIDW & 0,1 & 0,3 & 0,5 & 0,1 & 0,8 & 0,8 & 0,3 & 0,4 & 0,3 & 0,3 & & & & & & & & & & \\
\hline MIRT & 0,2 & 0,0 & 0,2 & 0,2 & 0,1 & 0,1 & 0,1 & 0,4 & 0,1 & 0,0 & 0,1 & & & & & & & & & \\
\hline PTSP & 0,1 & 0,1 & 0,3 & 0,0 & 0,5 & 0,2 & 0,5 & 0,3 & 0,3 & 0,1 & 0,3 & 0,2 & & & & & & & & \\
\hline PTAC & 0,0 & 0,1 & 0,3 & 0,0 & 0,2 & 0,1 & 0,3 & 0,2 & 0,1 & 0,1 & 0,2 & 0,3 & 0,3 & & & & & & & \\
\hline PTBG & 0,0 & 0,3 & 0,4 & 0,0 & 0,7 & 0,5 & 0,5 & 0,3 & 0,3 & 0,3 & 0,6 & 0,0 & 0,5 & 0,1 & & & & & & \\
\hline PTBL & 0,0 & 0,3 & 0,4 & 0,0 & 0,5 & 0,5 & 0,2 & 0,4 & 0,1 & 0,3 & 0,6 & 0,2 & 0,2 & 0,1 & 0,5 & & & & & \\
\hline PTCV & 0,0 & 0,3 & 0,4 & 0,0 & 0,5 & 0,5 & 0,2 & 0,4 & 0,4 & 0,3 & 0,5 & 0,0 & 0,2 & 0,1 & 0,6 & 0,5 & & & & \\
\hline PTCF & 0,2 & 0,3 & 0,4 & 0,0 & 0,6 & 0,6 & 0,5 & 0,3 & 0,1 & 0,3 & 0,6 & 0,0 & 0,3 & 0,1 & 0,8 & 0,5 & 0,5 & & & \\
\hline PTCN & 0,3 & 0,1 & 0,3 & 0,1 & 0,4 & 0,2 & 0,4 & 0,2 & 0,4 & 0,2 & 0,3 & 0,2 & 0,3 & 0,5 & 0,2 & 0,1 & 0,1 & 0,2 & & \\
\hline PTCO & 0,0 & 0,0 & 0,1 & 0,0 & 0,1 & 0,0 & 0,3 & 0,0 & 0,1 & 0,1 & 0,1 & 0,1 & 0,6 & 0,1 & 0,4 & 0,0 & 0,1 & 0,3 & 0,2 & \\
\hline PTVR & 0,2 & 0,1 & 0,3 & 0,0 & 0,4 & 0,1 & 0,6 & 0,3 & 0,2 & 0,1 & 0,3 & 0,2 & 0,6 & 0,5 & 0,4 & 0,1 & 0,1 & 0,4 & 0,4 & 0,4 \\
\hline
\end{tabular}

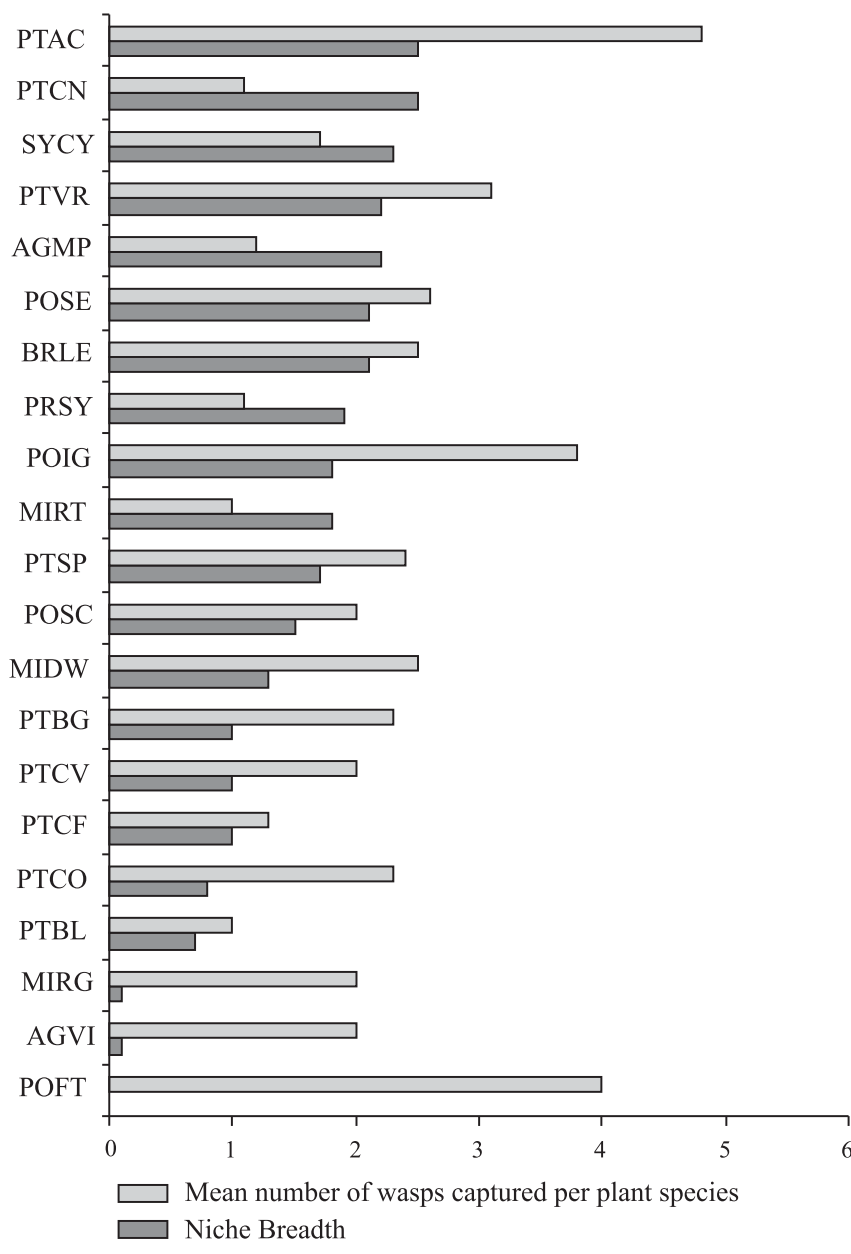

Fig. 5. Trophic niche breadth and mean number of polistine wasps captured per plant species in the Green Belt of Santa Cruz do Sul. Acronyms as in Table I. stated above, this species had the widest floral resource spectrum, visiting plant species of a large number of families. Polistes actaeon, as well as Synoeca cyanea, Polybia sericea, Polybia ignobilis, and Polistes versicolor are indicator species of the Green Belt of Santa Cruz do Sul, thus being plotted far from the area where the $\mathrm{CPCN}$ is plotted in the graphic. There is, indeed, a high concordance between DCA and the Indicator Species Analysis (IndVal) (see Table V).

In the right side of the Axis 2 is plotted the CPCN Pró-Mata of São Francisco de Paula. It is evident that this area presented a much more even spectrum of floral resources visited by the polistines. Almost all plant families are plotted together in the center of the area, surrounded by the abundant polistine visitors. Only the family Rosaceae is plotted far from the other families, because it was not visited by the indicator species of this area, Polybia platycephala and Polybia minarum (Table V). These two species are, for this reason, placed far from the area where the Green Belt is plotted.

Table IV. Trophic niche overlap of polistine wasps in the CPCN Pró-Mata of São Francisco de Paula. Acronyms as in Table I.

\begin{tabular}{|c|c|c|c|c|c|c|c|c|c|c|}
\hline \multirow{2}{*}{$\overline{\mathrm{AGMP}}$} & AGMP & $\mathrm{AC}$ & \multicolumn{2}{|c|}{ BRLE POSP } & POIG & POM & \multicolumn{2}{|c|}{ POPT } & \multicolumn{2}{|c|}{ PRSY MDW } \\
\hline & & & & & & & & & & \\
\hline AGVI & 0,2 & & & & & & & & & \\
\hline BRLE & 0,0 & 0,1 & & & & & & & & \\
\hline POSP & 0,0 & 0,0 & 0,0 & & & & & & & \\
\hline POIG & 0,0 & 0,0 & 0,0 & 0,0 & & & & & & \\
\hline POMN & 0,2 & 0,3 & 0,1 & 0,0 & 0,0 & & & & & \\
\hline POPT & 0,1 & 0,2 & 0,5 & 0,0 & 0,0 & 0,7 & & & & \\
\hline POSC & 0,0 & 0,1 & 0,0 & 0,0 & 0,0 & 0,4 & 0,2 & & & \\
\hline PRSY & 0,1 & 0,1 & 0,4 & 0,0 & 0,0 & 0,3 & 0,6 & 0,0 & & \\
\hline MIDW & 0,1 & 0,1 & 0,5 & 0,0 & 0,0 & 0,1 & 0,5 & 0,0 & 0,3 & \\
\hline PTPF & 0,0 & 0,0 & 0,0 & 0,0 & 0,0 & 0,0 & 0,0 & 0,0 & 0,0 & 0,0 \\
\hline
\end{tabular}




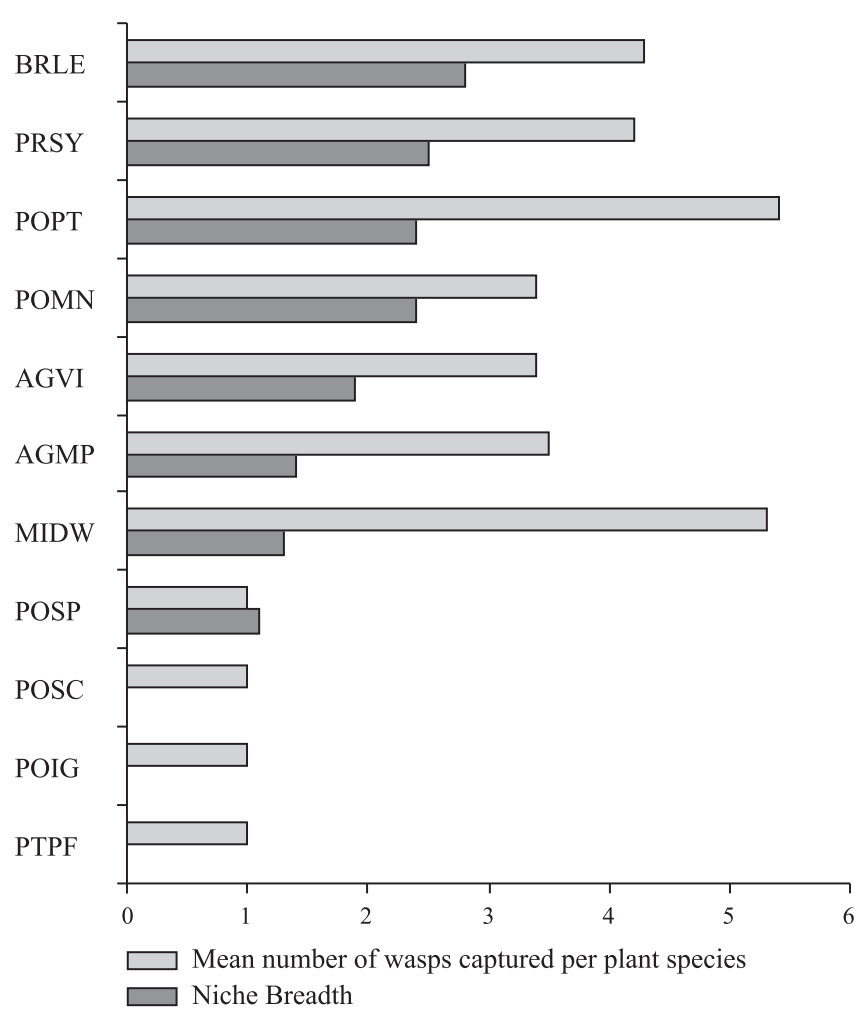

Fig. 6. Trophic niche breadth and mean number of polistine wasps captured per plant species in the CPCN Pró-Mata of São Francisco de Paula. Acronyms as in Table I.

\section{DISCUSSION}

Floral Spectrum Visited by the Polistinae wasps. The Polistinae nurse their brood; consequently, their food requirements are great. One remarkable example is the case of the epiponine Agelaia vicina, whose nest may achieve a very large size, with the colony comprising over a million adult individuals (Zucchi et al. 1995). The polistines are primarily animals of prey and the diet of their larvae chiefly consists of animal protein. Their interest for carbohydrates is regarded as maintenance of their own energy metabolism (Faegri \& Pijl 1979), and the nectar collected by the polistines is, indeed, a complement of their diet. Agelaia vicina was not, however, considered an abundant flower visitor in both study sites, foraging mainly on plant species that offered nectar. On the contrary, some species of Polistes and Brachygastra even store nectar for the brood in addition to animal food. The same is true for the species Brachygastra lecheguana in CPCN Pró-Mata.

Asteraceae was the most visited plant family in both studied localities. However, this is not to be considered a floral preference expressed by the polistines, but related to the large number of asteracean species that are widely found in the state of Rio Grande do Sul. In the Green Belt of Santa Cruz do Sul, 33,3\% of the visited plant species were asters, while in the CPCN Pró-Mata of São Francisco de Paula this number reached up to $40 \%$. In addition, aster inflorescences and "brush-blossoms" resemble many plants in which numbers of small flowers are massed together in less specialized, but more or less compact inflorescences, thus achieving a much more conspicuous display than would scattered single flowers (Proctor et al. 1996). Also, due to their large nectar resource, which is concealed at a depth of some millimeters only, and the presence of yellow and white flower coloration and variously produced shine or luster, the aster species present a more effective attraction to insects than do other plant families. Faegri \& Pijl (1979) stated that some wasps have tube-like modified mouth-parts of 5-10 mm long, through which nectar can be sucked up. The higher number of polistine wasp species collected while visiting inflorescences of Asteraceae was also observed by Silberbauer-Gottsberger \& Gottsberger (1988) in the Brazilian Cerrado and Vogel (1954) in South Africa.

Apiaceae was also commonly visited by social wasps in the Green Belt of Santa Cruz do Sul. The umbels themselves are conspicuous from a distance, and their flat tops provide a convenient landing platform for insects, and nectar and pollen are both freely exposed to all comers (Proctor et al. 1996). The wasps frequently spend considerable time taking nectar, although they may also be attracted by the presence of flies for prey. However, differently from the Asteraceae, only two wasp-visited species of Apiaceae were recorded in the Green Belt, Eryngium horridum being commonly visited by the polistines. This species is very common in human modified areas, growing massively and blooming during periods of low food resource.

Flowers of the cunoniacean Lamanonia speciosa are grouped in numerous inflorescences, blooming massively in the spring and summer months. Its geographic distribution is limited to high altitude areas of the northeast region of Rio

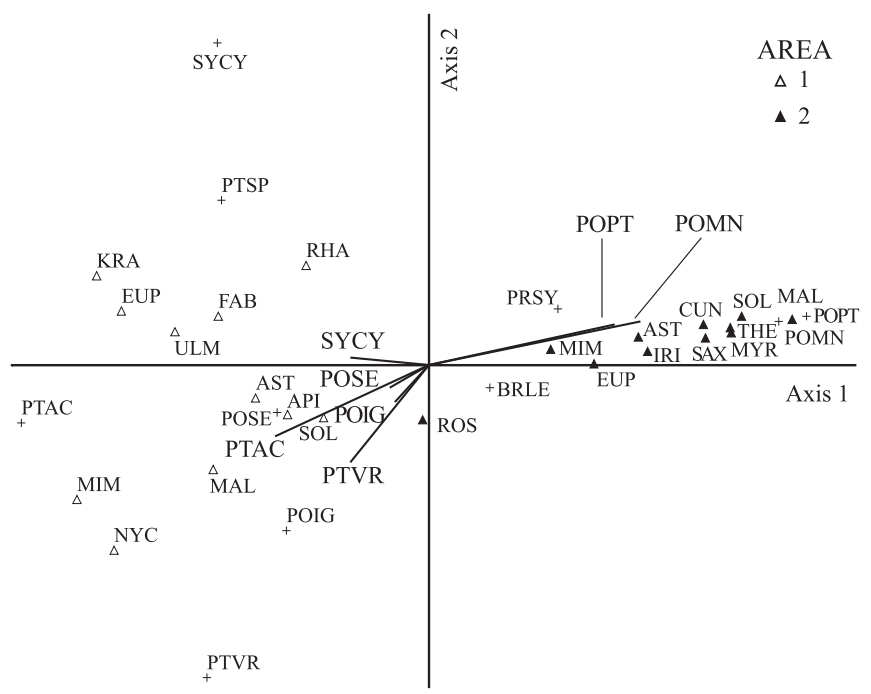

Fig. 7. Detrended Correspondence Analysis, using the abundant flowervisitor species of Polistinae in the study sites (Figs. 1 and 2) and the most visited plant families (Figs. 3 and 4). Cumulative variability in the two axis $=55,3 \%$ according to the Euclidean Relative Distance. Open triangles $=$ most visited plant families in area 1 (Green Belt). Closed triangles $=$ most visited plant families in area $2(\mathrm{CPCN}$ PróMata). Crosses $=$ Polistinae species. Acronyms as in Tables I and II. 
Table V. Indicator Species Analysis (IndVal). The sampling sites were used as variable group from the main matrix. The Monte Carlo test was performed using 10.000 runs. Only the statistical significant results are shown $(\alpha=0,05)$. Acronyms as in Table I.

\begin{tabular}{lccc}
\hline Species & Area & Indicator Value & $\mathrm{p}$ \\
\hline POPT & CPCN & 61,9 & 0,0001 \\
POMN & GPCN & 57,1 & 0,0002 \\
PTAC & GB & 60,0 & 0,0002 \\
PTVR & GB & 50,0 & 0,0004 \\
POIG & GB & 39,3 & 0,0066 \\
SYCY & GB & 35,0 & 0,0035 \\
PTCN & GB & 35,0 & 0,0031 \\
POSE & GB & 30,0 & 0,0079 \\
PTSP & GB & 20,0 & 0,0483 \\
\hline
\end{tabular}

Grande do Sul state, where CPCN Pró-Mata is located. Nectar is offered by the flowers in the early morning hours, attracting many visitors, including individuals of seven polistine species in CPCN Pró-Mata of São Francisco de Paula.

The large number of visitors of Asteraceae species in both localities is not likely to generate specialized dependences on the part of the wasps. It is clear that the vespids are generalist visitors of flowering plants, mainly because of the need of perennial colonies of some species (mainly species of the tribe Epiponini) for a permanent food supply. Those plant species/ families that offer a large quantity of nectar in avoidance to pollen tend to be more frequently visited by the vespids.

Acknowledgements. We thank Marcos E. G. Sobral, Nelson I. Matzenbacher, Jair Putzke and Luciano Pedroso for plant species identification; Birgit Harter-Marques for providing data of CPCN PróMata; Angélica Oliveira and Guilherme Hermany for statistical support; Bolivar R. Garcete-Barrett and James M. Carpenter for suggestions on earlier versions of the manuscript and help on social wasps identification.

\section{REFERENCES}

Alves, E. L. \& E. Collischon. 2001. Cinturão Verde: da preservação a especulação - uma análise ambiental. Laboratório de Geoprocessamento, Universidade de Santa Cruz do Sul, CD.

Carpenter, J. M. \& O. M. Marques. 2001. Contribuição ao Estudo dos Vespídeos do Brasil. Salvador, Universidade Federal da Bahia, Departamento de Fitotecnia. Série Publicações Digitais, v. 3, CD. Carvalho, C. A. L. de; Marques, O. M. \& H. S. de V. Sampaio. 1995.
Abelhas (Hymenoptera, Apoidea) em Cruz das Almas - Bahia: 1 Espécies coletadas em fruteiras. Insecta 4: 11-17.

Colwell, R. K. \& D. J. Futuyama. 1971. On the measurement of niche breadth and overlap. Ecology 52: 567-576.

Dufrene, M. \& P. Legendre. 1997. Species assemblages and indicator species: the need for a flexible asymmetrical approach. Ecological Monographs 67: 345-366.

Faegri, K. \& L. Van der Pijl. 1979. The principles of pollination ecology. London, Pergamon Press Ltda., 244 p.

Harter-Marques, B. \& W. Engels. 2003. A produção de sementes de Mimosa scabrella (Mimosaceae) no Planalto das Araucárias, RS, depende da polinização por abelhas sem ferrão. Biociências 11: $9-16$.

Hill, M. O. 1973. Reciprocal averaging: an eigenvector method of ordination. Journal of Ecology 61: 237-249.

Hill, M. O. \& H. G. Gauch. 1980. Detrended correspondence analysis: an improved ordination technique. Vegetatio 42: 47-58.

Lobo, E. A. \& G. Leighton. 1986. Estruturas comunitárias de las fitocenosis planctónicas de los sistemas de desembocaduras de ríos y esteros de la zona central de Chile. Revista Biología Marina 22: 1-29.

McCune, B. \& M. J. Mefford. 1999. PC-ORD. Multivariate Analysis of Ecological Data, Version 4.10. Gleneden Beach, Oregon, MjM Software Design, 237 p.

Pielou, E. C. 1972. Niche width and niche overlap: a method for measuring them. Ecology 53: 687-692.

Proctor, M., Yeo, P. \& A. Lack. 1996. The natural history of pollination. Hampshire, Harper Collins Publishers, 479 p.

Richards, O. W. 1978. The social wasps of the Americas excluding the Vespinae. London, British Museum of Natural History, 580 p.

Sakagami, S. F.; Laroca, S. \& J. S. Moure. 1967. Wild bee biocenotics in São José dos Pinhais (PR), south Brazil. Preliminary report. Journal of the Faculty of Hokkaido University (Zoology) 16: 253-291.

Schlindwein, C. \& D. Wittman. 1995. Specialized solitary bees as effective pollinators of south Brazilian species of Notocactus and Gymnocalycium. Bradleya 13: 25-34.

Silberbauer-Gottsberger, I. \& G. Gottsberger. 1988. A polinização de plantas do cerrado. Revista Brasileira de Biologia 48: 651663.

Vogel, S. 1954. Blütenbiologische Typen als Elemente der Sippengliederung dargestellt anhand der Flora Südafrikas. Jena, Gustav Fischer Verlag, 338 p.

Wilms, W.; Imperatriz-Fonseca, V. L. \& W. Engels. 1996. Resource partitioning between highly eusocial bees and possible impact of the introduced Africanized honey bee on native stingless bees in the Brazilian atlantic rainforest. Studies on Neotropical Fauna and Environment 31: 137-151.

Wilms, W.; Wendel, L.; Zillikens, A.; Blochtein, B. \& W. Engels. 1997. Bees and other insects recorded on flowering trees in a subtropical Araucaria forest in Southern Brazil. Studies on Neotropical Fauna and Environment 32: 220-226.

Zucchi, R.; Sakagami, S. F.; Noll, F. B.; Mechi, M. R.; Mateus, S.; Baio, M. V. \& S. N. Shima. 1995. Agelaia vicina, a swarm-founding polistine with the largest colony size among wasps and bees (Hymenoptera: Vespidae). Journal of the New York Entomological Society 103: 129-137. 